\title{
A Study on Economic Security of Self-Employed Women in a Low Income Community in the City of Colombo
}

By

\section{Weeresinghe Wasala Mudlyanselage Ananda Sarath Premakumara}

Fhesis submitted to the University of Sri Jayewardemepura for the award of the degree of Master of Science on Human Security 


\section{A Study on Economic Security of Self-Employed Women in a Low Income Community in the City of Colombo}

Weerasinghe Wasala Mudiyanselage Ananda Sarath Premakumara

The Master of Science Degree in 


\section{Acknowledgement}

I am grateful to the Department of Geography of the University of Sri Jeyewardenepura for conducting this MSc Degree Programme and to Senior Professor M.M. Karunanayake and Dr. C. Deheragoda for the guidance given me in all aspects.

I wish to express my sincere gratitude and appreciation to Professor Y.A.D.S. Wanasinghe who supervised the project and gave valuable guidance to successfully complete the study.

I also wish to thanks Mr. A.G.W. Nanayakkara, Director General of the Department of Census and Statistics for encouraging me at all times and providing relevant information used in the study.

I wish to acknowledge valuable deliberation by all the lecturers involve in this MSc Degree Course helped me to finish this study successfully.

W.W.M.A.S. Premakumara 
The work described in this thesis was carried out by me under the supervision of Professor Y.A.D.S. Wanasinghe and a report on this has not been submitted in whole or in part to any University for another Degree or Diploma.

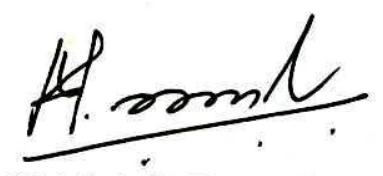

W.W.M.A.S. Premakumara

I certigy har this statement is cerrect.

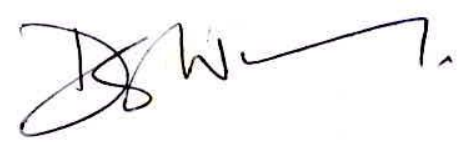

$$
\begin{aligned}
& \text { Py. YAD.S. Wancsmy h. } \\
& \text { bflopoos DSh? }
\end{aligned}
$$




\section{Chapter 01}

$\begin{array}{ll}1.1 \text { Low Income Community } & 02\end{array}$

$\begin{array}{ll}1.2 \text { Self-Employment } & 03\end{array}$

$\begin{array}{ll}1.3 \text { Significance of the study } & 03\end{array}$

$\begin{array}{ll}1.4 \text { The study area } & 04\end{array}$

$\begin{array}{ll}1.5 \text { Objective of the study } & 05\end{array}$

$\begin{array}{ll}\text { 1.6 Survey methodology } & 07\end{array}$

$\begin{array}{ll}\text { 1.7 Data Collection } & 07\end{array}$

$\begin{array}{ll}1.8 \text { Organization of the report } & 09\end{array}$

Chapter 02

CHARACTERISTICS OF URBAN POVERTY AND WEMEN

$\begin{array}{ll}2.1 \text { The urban poor } & 10\end{array}$

2.2 Characteristics of urban poverty 11

$\begin{array}{ll}2.3 \text { Urban poverty in low-income community } & 13\end{array}$

2.4 Linkage between low income and poverty 14

$\begin{array}{ll}2.5 \text { The situation of women } & 15\end{array}$

$\begin{array}{ll}\text { 2.6 Participation of women in the labour force } & 17\end{array}$

2.7 Role of women in the City 20

$\begin{array}{ll}\text { Chapter } 03 & 21\end{array}$

OVERVIEW OF URBAN SELF-EMPLOYMENT

3.1 Location and physical characteristics of the work place 21

3.2 Characteristics of Self Employed Women 23

3.3 Income distribution of female headed and male headed households 26 
LINKAGE WITH MARKET

4.1 Demands and Competition

4.2 Other constraints on growth and productivity

Chapter 5

INCOME OF SELF EMPLOYED WOMEN

$\begin{array}{lll}5.1 & \text { Earnings and profitability } & 42\end{array}$

$\begin{array}{ll}\text { Chapter } 6 & 45\end{array}$

CONCLUTION

6.1 Major finding of the study $\quad 45$

6.1.1 Factors relating to entry $\quad 45$

6.2 Income and profitability 46

$\begin{array}{ll}6.3 \text { Conclusion } & 46\end{array}$

$\begin{array}{ll}\text { References } & 49\end{array}$

Appendix 51

$\begin{array}{ll}\text { Questionnaire } & 65\end{array}$ 
Table 01- Income over expenditure 51

Table 02- Monthly Household expenditure of Low Income Household 51

Table 03- Monthly expenditure on foods of Self-employed

Women in a Low Income Community

Table 04 - Income, Expenditure and Savings by Level of Education of Self-employed Women in a Low Income Community

Table 05 - Income, Expenditure and Savings by Civil status of Self-employed Women in a Low Income Community

Table 06 - Age distribution of self employed women

Table 07 - Level of Education of self employed women

Table 08 - Marital Status of self employed women

Family Background and Source of Income

Table 09 - Type of Activity of self employed women

Table 10 - Household size of self employed families

Table 11 - Daily income of self employed woman 54

Table 12 - Daily Turnover of the businesses of self employed women 55

Table 13 - Daily Household Income of self employed women

Table 14 - Number of Dependents of self employed families

Table 15 -Number of Children of self employed woman

Table 16 -Husband's Occupation of self employed women

Table 17 -Husband's daily Income

Table 18 -Husbands who economically Supports the family

Table 19 -Service of self employed women

Table 20 -Adequacy of Sufficient Income 
Table 22 -Owner of the House

Table 23 - Ownership of the house

Table 24 - Type of House

Table 25 - Roof Type

Table 26 - Type of Floor

Table 27 - Type of wall

Table 28 - Availability of Television

Table 29 - Availability of Radios

Table 30 -Availability of Other Assets

Table 31 -Availability of Vehicles

Table 32 -Savings of Self employed women (Rs.)

Migration

Table 33 - Place of birth

Table 34 - Reasons for Migrate

Health conditions and environment

Table 35 - Health Condition

Table 36 - Medicine for Diseases

Table 37 - Environment and health

Table 38 - Environment of working place

Table 39 - Environment of around the working place 
Table 41 - Environment and self employed women

Investment

Table 42 - Year when Business began

Table 43 - Investment for the business

Table 44 - Sources of investment

Table 45 - Sources of Loan

Table 46 - Borrowed money

Table 47 - Location of Work places

Table 48 - Reasons for Select the business places

Table 49 - Type of building

Table 50 - Owner of the building

Table 51 - Self employed women who are living under the threats

Table 52 - Customers of self-employed women

Table 53 - Average Income by type of activity 


\section{Chapter 01 \\ INTRODUCTION}

In Sri Lanka, as in other developing countries, self-employment contributes significantly to the income of most households. In the agricultural sector, employment is dominated by self-employment in the form of family farms using mainly family labour, with the help of hired labour. In Sri Lanka this type of agricultural self-employment accounted for 35 per cent of the total employed labour force in 2003. In urban areas too, the informal sector dominates employment activities.

Sri Lankan planners have been paying increasing attention to self-employment activities in recent years. The formal sector cannot be expected to generate sufficient demand for labour to absorb the new additions to the labour force, let alone reduce the existing unemployment and under employment. Moreover, the employment situation is expected to deteriorate further in the near future due to adverse economic conditions of the country.

Against this background, the Sri Lankan Government has identified the promotion of self-employment as one of the strategies to alleviate urban and rural unemployment, especially among new entrants to the labour force. The major advantages of such a strategies are seen to lie in the vast employment generation potential of small enterprises, paired with their relatively low capital requirement for setting up an enterprises and the use of simple technology. Thus it is envisaged that this sector (in urban and rural areas) 
can provide viable employment opportunities for those without rigorous training and large amounts of capital, who have little chance to become employed as wage and salary earners in the formal sector.

\subsection{Low Income Community}

The question of defining whether a community is low income or high income has to be considered in relative terms. With regard to low income groups within specific settlements can be determined by the percentage of households that would broadly be categorized as "low income" by the following definition of the Department of Census and Statistics, which defines poor families as follows: "households that spend more than 50 percent of their expenditure on food and average adult equivalent food expenditure is less than Rs.1338.48 per adult per month are considered as poor households". According to the definition, 7.6 percent of the urban households are poor and 44.5 percent of households in the lowest income deciles are poor.

In this study, low-income self-employed woman are defined as follows: average per capita expenditure of first five income deciles of the Household Income and Expenditure Survey was the indicator for define low income group in the City of Colombo. It was Rs. 1,327 in 2002 . In another words average family expenditure for food was Rs. 5,500 per month (Family size of Household Income and Expenditure Survey (HIES) was 4.2). 
Based on this value, the 28 self-employed women who were selected either spend equal or less than Rs. 1,327 per month for food, or belongs to families who spend Rs. Less than 5,500 for food per month.

\subsection{Self-employment}

Self employment is 'working independently for customers or clients and not for employer"

According to the definition, self-employed women can be defined as follows.

Self-employed women who earn a living through their own small business or through their own labour.

In this study, self-employed women in Colombo were categorized into three types.

1. Hawkers and vendors who sell their wares from carts, baskets or small shops. They sell vegetables, fish, fruit, prepared food, household goods, clothes and other items.

2. Home based workers who prepare breakfast or lunch for sale, dressmakers and others who work at home.

3. Service providers: (vegetable and fruits sellers), who work as manual labourers or are engaged in laundry services and domestic services.

The economic security of people is defined as these who receive "an assured basic income usually from productive and remunerative work, or in the last resort from some publicly financed safety net." (Human Development Report, 1994)

\subsection{Significance of the study}

Over 52 percent of the population in urban low-income communities in the City of Colombo constitutes women, but their economic role has not yet been studied in depth. In 1994, females headed 21.4 percent of low-income households. In 1992 it was 18.8 
percent and in 1993 the proportion had increase to 20.3 percent. This ratio is expected to increase. Therefore women's role in ensuring economic security of their households will be become more important. The information on self-employment in urban low-income community is as yet rather limited. The available information focuses mainly on specific aspects of self-employment and does not provide a compreherisive picture to assist planners in policy formulation and implementation.

The majority of the women in the urban low income communities are engaged in some form of economic activity that is are often recognized but exactly not valued. It should be noted that women in urban low-income communities perform important economic functions and that the potential of economic security of urban women in low-income group is substantial.

\subsection{The study area}

Low-income families are spread through out the Colombo Municipality area. However certain areas in Colombo can be considered as relatively better than other areas. These comprise, Cinnamon Garden, parts of Wellawatta, Bambalapitya and Kollupitiya wards. On the other hand there are areas in Colombo Municipality where there is a higher stress in terms of poverty levels. One of these areas has been identified to be Wanathamulla Grama Niladhari (GN) Division, where also exist some of the poorest families in the City. Based on these information it has been decided to select this area for the study. 
Demographic and housing information of study area

Table 1.1 - Population

\begin{tabular}{|l|r|r|r|r|r|}
\hline Area & Total & Male & Female & Less than 18 years & 18 years \& over \\
\hline Colombo city & 642,020 & 342,529 & 299,491 & 180,285 & 461,735 \\
\hline Thimbirigasyaya DSD & 264,624 & 138,923 & 125,701 & 66,679 & 197,945 \\
\hline Wanathamulla ward & 14,023 & 6,997 & 7026 & 4,708 & 9,315 \\
\hline
\end{tabular}

Source: Department and Census and Statistics

Table 1.2 - Low-income household

\begin{tabular}{|l|r|r|r|}
\hline & $\begin{array}{r}\text { Total } \\
\text { Households }\end{array}$ & $\begin{array}{r}\text { Male headed } \\
\text { Households }\end{array}$ & $\begin{array}{r}\text { Female headed } \\
\text { Households }\end{array}$ \\
\hline Low Income & 423 & 198 & 225 \\
Households* & 28 & 11 & 17 \\
\hline Sample Size (7\%) & & & \\
\hline
\end{tabular}

Source: Department and Census and Statistics, *DS Thimbirigasyaya / GN Wanathamulla

There are 423 low-income (monthly income less than Rs. 7000) families living in the

Wanathamulla GN Division, of which 225 are low-income female-headed households.

Most of low income communities are located in and around Seevalepura, Base Line

Mawatha, Dump watta, Sahaspura, Weluwanapura, T20 watta, T45 watta, T56 watta and

Saranapala Himi Mawatha etc.

\subsection{Objectives of the study}

Earlier studies had focused on low-income housing and income levels in general. Especially Urban Development Authority, focused on housing construction and Department of Census and Statistics conduct Labour Force and Household expenditure surveys in National level. These, available information do not offer substantial or sufficiently in-depth information on the subject of self-employment of women in urban low-income community in the City of Colombo. 
The study set out with the following objectives;

\section{General}

(i) To identify the major economic security issues of women in a selected lowincome community in the City of Colombo.

\section{The specific objectives are to}

a) identify the different types of employment that low income women are engaged

b) analyze income and expenditure patterns of self employed women in a lowincome community

c) examing the major problems associated with self-employment

The analysis, mentioned under the objectives, was focused on the following aspects:

a) The major self-employment activities and the scale of operation;

b) Factors determining initial entry into self-employment activities

c) The impact of such activities on the income of households;

d) The source of funding of the self-employment activities, and the scale of investment;

e) The nature of the product and services provided;

f) The level of skill, technology and training involved;

g) Characteristics of demand and supply;

h) Consumption patterns and expenditure on food and other necessities

i) Nature of the savings (assets) 